\title{
The significance of hydrothermal alteration zones for the mechanical behavior of a geothermal reservoir
}

\author{
Carola Meller ${ }^{*}$ and Thomas Kohl
}

\author{
* Correspondence: \\ carola.meller@kit.edu \\ Institute of Applied Geosciences, \\ Division of Geothermal Research, \\ Karlsruhe Institute of Technology \\ (KIT), Adenauerring 20b, 76131 \\ Karlsruhe, Germany
}

\begin{abstract}
Background: The occurrence of hydrothermally altered zones is a commonly observed phenomenon in brittle rock. The dissolution and transformation of primary minerals and the precipitation of secondary minerals affect rocks in terms of mechanics, stress conditions, and induced seismicity.

Methods: The present study investigates commonly observed phenomena of hydrothermal alteration and observations at the geothermal site of Soultz-sous-Forêts, which are related to the occurrence of hydrothermal alteration. Geomechanical observations at Soultz are interpreted on the basis of synthetic clay content logs, which are created from borehole logging data, and which identify clay in hydrothermally altered zones.

Results: It is shown that hydrothermal alteration results in a reduction of the frictional strength of the reservoir rock. Weak zones can act as stress-decoupling horizons, which locally perturb the stress field and affect the evolution of the microseismic cloud. For the first time, it is shown on a reservoir scale that large magnitude seismic events are restricted to unaltered granites, whereas in clay zones, only small magnitudes are observed. It is demonstrated that clay-rich zones foster the occurrence of aseismic movements on fractures.

Conclusions: Secondary mineral precipitation during hydrothermal alteration has a great effect on the geomechanical properties of a geothermal reservoir. The identification of such zones is a first step towards understanding the relation between alteration and mechanical processes inside a reservoir and can help in reducing induced seismicity during hydraulic stimulation of a reservoir.
\end{abstract}

Keywords: Geothermal reservoir; Hydrothermal alteration; Aseismicity; Reservoir hydraulics; Soultz-sous-Forêts; Clay

\section{Background}

The importance of clay zones for the geomechanical structure and the earthquake mechanics in brittle rock became an important issue in the framework of mitigation studies of natural and man-made disasters (Holmes et al. 2013). A strong focus was given to hydrothermal alteration in crystalline rock and its effect on mechanical friction. Recent studies on the San Andreas Fault revealed the significant impact of clay inside faults and fractures on their mechanical and hydraulic properties. Faults and fractures are target zones for enhanced geothermal systems (EGS), as they provide pathways for

(c) 2014 Meller and Kohl; licensee Springer. This is an Open Access article distributed under the terms of the Creative Commons Attribution License (http://creativecommons.org/licenses/by/4.0), which permits unrestricted use, distribution, and reproduction in any medium, provided the original work is properly cited. 
geothermal fluids. In terms of mitigation of induced seismicity, while increasing the permeability of the geothermal reservoir, detailed understanding of hydraulic and mechanical processes of fractured rock is the key for the success of an EGS project.

\section{The significance of clay for geothermal projects}

The development of EGS in low-enthalpy regions like the Upper Rhine Graben in central Europe involves the application of hydraulic stimulation for permeability enhancement in the geothermal reservoir. Mostly located near residential areas, there is a claim for safety and controllability of the geothermal technology from the public. In the past, people were concerned by the occurrence of small perceptible earthquakes, caused by stimulation activities or during operation of geothermal power plants like the magnitude $M_{\mathrm{L}}=3.4$ earthquake in Basel in 2006 (e.g., Häring et al. 2008), the $M_{\mathrm{L}}=2.9, M_{\mathrm{L}}=2.5$, and $M_{\mathrm{L}}=2.3$ in Soultz-sous-Forêts in 2003, 2000, and 2004 (Dorbath et al. 2009), respectively, or the $M_{\mathrm{L}}=2.4$ and $M_{\mathrm{L}}=2.7$ earthquakes near Landau in 2009 (Groos et al. 2013). The injection of fluid into the underground changes the effective stress, thus inducing slips on fractures and faults associated with seismic events in brittle rock. In order to predict or even control the seismic behavior of a geothermal reservoir, the geomechanical structures and the associated processes must be known.

In fresh and homogeneous rock, the relation between stress and mechanical failure is commonly described by the Mohr-Coulomb criterion (Scholz 2010) with flow through fractures to be characterized as sublaminar by the Darcy flow (Sausse 2002). In geothermal reservoirs, however, the percolation by geothermal brine promotes the formation of hydrothermally altered zones around fluid pathways. The dissolution of primary rock-forming minerals and the precipitation of secondary minerals like quartz, clay, or carbonates change the in situ conditions with respect to mechanical strength of the rock. In such zones, simple models might no longer apply, and the reservoir behavior is difficult to assess. Evidence, that simple rock mechanical models no longer account during and especially after the shut-in of hydraulic stimulation, has been only recently highlighted by Schoenball et al. (2014) who demonstrated a change in the stress regime during stimulation.

Several studies demonstrate the relation between geomechanics, earthquake characteristics, and the weakness of rocks on a crustal and regional scale. For geothermal projects, however, the geomechanical properties of a reservoir are to be known on a very local scale in the order of several meters. The size of hydrothermal alteration zones can range from millimeters to several kilometers. In order to characterize a geothermal reservoir and to assess its geomechanics, it is important to understand the significance of such alteration zones. Therefore, it is necessary to know and to understand, if and how large-scale geomechanical rules and observations can be transferred to the reservoir scale.

The present paper conducts an investigation on the significance of hydrothermal alteration in the granite of the geothermal site in Soultz-sous-Forêts (France) and the change of its mechanical parameters. The basis of the analyses is synthetic clay logs, which are created from spectral gamma ray logs using a technique introduced by Meller et al. (2014a). These logs are indicative of the occurrence of clay-bearing fractures along the boreholes. The newly derived results are investigated under the light of the existing geomechanical interpretation, which is summarized in the 'Current state of research on the role of clay in fault zones' subsection. 


\section{Current state of research on the role of clay in fault zones}

Evidence for the role of clay as zones of weakness or some kind of lubricant on faults promoting aseismic movements has been described by Schleicher et al. (2006), Dolan et al. (1995), and Wu et al. (1975). Clay minerals are a characteristic of creeping faults with rates of up to $30 \mathrm{~mm} / \mathrm{a}$ assumed for the San Andreas Fault (Chang et al. 2013). Studies on the slipping behavior of the San Andreas Fault, however, suggest that it is not merely creeping but it rather consists of creeping patches, which build up stress on patches with high friction. If the stress is large enough, these high friction patches rupture and cause seismic events (e.g., Chang et al. 2013). This theory is supported by the work of Amelung and King (1997) who observed a continuous earthquake activity on creeping faults. A major result of their study is that creep and earthquakes are not two separated phenomena, but two processes which go hand in hand. This has been reported earlier for numerous faults and continental margins (e.g., Brune 1968; Voisin et al. 2004; Mulargia et al. 2004). Recent studies at the geothermal site in Soultz-sous-Forêts revealed similar mechanisms during shear movements on faults. Bourouis and Bernard (2007) observed in the data of seismicity induced during GPK1 stimulation repeated shear movements on fault asperities surrounded by creeping zones. Schmittbuhl et al. 2014 observed in the laboratory experiments a close relationship between seismic and aseismic movements on faults and conclude that aseismic processes can drive seismicity, almost independent from fluid pressure. The triggering of seismic events by creep movements is an important issue for EGS and needs to be considered for the mitigation of large seismic events (Figure 1).

Clay minerals, which are a main product of hydrothermal alteration (e.g., Meunier 2005; Velde 1995), sometimes have very low friction coefficients of approximately 0.3 (e.g., Morrow et al. 1992 and references herein, and c.f. Figure 1b). The frictional properties of clay minerals, however, strongly depend on their structure and water content. Therefore, it is not easy to estimate the frictional properties of clay-filled faults (Moore and Lockner 2007). Many studies have been conducted on the relationship between the nature of fracture fillings and fault mechanics. Zoback et al. (2012) and Kohli and Zoback (2013) investigated the relationship between clay content and the mechanical friction of shale gas reservoir samples under wet conditions. They observed a linear decrease of the friction coefficient with increasing clay content (Figure 1a) from 0.8 with 10 wt.\% clay to 0.4 at approximately $50 \mathrm{wt}$ \% clay. Similar results have been obtained by Tembe et al. (2010) for artificial clay gouge samples of quartz and illite and for natural soil samples tested by Akayuli et al. (2013). The friction coefficients they measured for different clays vary and are much lower than those of other minerals like quartz or feldspars (Figure 1b).

The rupture behavior of a fault from the Dieterich-Ruina constitutive model (Ruina 1983; Dieterich 1978) describes the frictional evolution of a fault for different sliding velocities with the material parameter $(a-b)$ representing the difference in steady-state friction. It indicates stable sliding of fault surfaces during slip if $(a-b)>0$ or unstable sliding if $(a-b)<0$. The synonyms for stable and unstable sliding are velocity-strengthening and velocity-weakening behavior, respectively. The effect of clay on the rupture behavior of faults has been studied by many laboratory experiments. Ikaris et al. (2011) found experimental evidence for the relationship between the weakness of rocks and their frictional stability: rock samples with a low friction coefficient show velocity-strengthening behavior, whereas samples with high friction coefficients show velocity-weakening behavior 


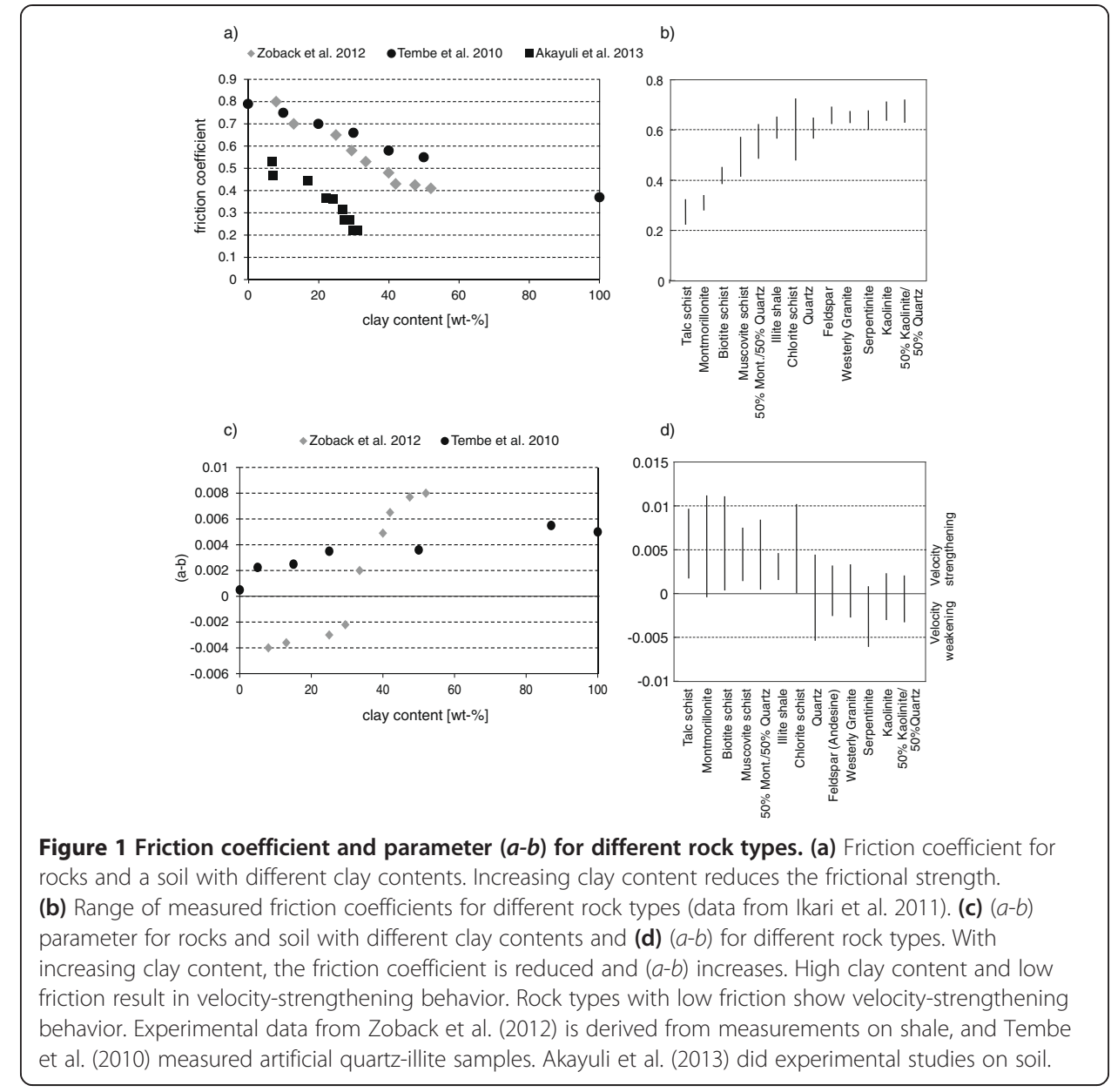

b)

(Figure 1). This indicates the occurrence of brittle failure only on rocks with high friction coefficients. Zoback et al. (2012) observed experimentally on shale gas samples that faults with clay contents higher than $30 \%$ slide stable (i.e., $(a-b)>0$ ), whereas faults with a lower clay content slip unstable (i.e., $(a-b)<0$, Figure 1 c). They reasoned that such clay-rich faults slide aseismically, whereas the faults with lower clay contents produce microseismic events. The dataset of Tembe illustrates a dependence of $(a-b)$ of illite-quartz samples on the illite content. For these samples, no velocity-weakening behavior is observed. The reason for this is that quartz can behave both velocity strengthening and velocity weakening, and under the experimental conditions, it was velocity-strengthening $(a-b)>0$ (Figure 1c), but nevertheless the effect of the clay proportion of the samples on $(a-b)$ is significant.

As the frictional properties of rocks determine their slipping behavior, a correlation between the weakness of the rocks and the occurrence of large and small earthquakes is expected. The so-called $b$-value, which is derived from the Gutenberg-Richter law (Gutenberg and Richter 1954), describes the proportion of small relative earthquakes to large ones. A $b$-value of 1 represents a logarithmic relationship between the magnitude of events and their frequency, whereas $b$-values $>1$ reflect an increased number of small earthquakes. High $b$-values are expected in areas where no large differential stress can build up. Schorlemmer et al. (2005) compared the results of numerous earthquakes from different settings and of laboratory data. They found that the $b$-value differs 
systematically with the faulting regimes. The highest $b$-values are found in normal faulting regimes (up to 1.2), whereas the lowest $b$-values occur in thrust events (as small as 0.6), and strike-slip events are in between. Based on the stress prevailing in the respective regimes, Schorlemmer et al. (2005) concluded that the $b$-value inversely correlates with differential stress levels. This was also confirmed by laboratory experiments performed by Amitrano (2003) who observed a decreasing $b$-value with increasing differential stress. Creeping fault sections show very high $b$-values of around 1.3 (Schorlemmer and Wiemer 2005). Based on these results, the occurrence of small events and aseismic movements in strongly altered and fractured areas is expected rather than large earthquakes. This assumption has also been proposed by Heinicke et al. (2009) who investigated the correlation between hydrothermal alteration and the occurrence of earthquake swarms. They observed in the Vogtland region of northwestern Bohemia that in addition to increased pore pressure and shear stress, the mechanical weakening of the rocks and the dissolution of fracture walls play an important role for the evolution of earthquake swarms. Interestingly, the maximum magnitude of such earthquake swarms is limited to 5 (Heinicke et al. 2009), which supports the theory of only small earthquakes occurring in regions with rocks of low friction coefficients. When analyzing $b$-values, one has to consider that this value is affected by numerous parameters, not least by the way it is computed. Besides the strength of the rock, the main affecting parameters are the stress field, the focal mechanism of the earthquakes, and the presence of large geologic structures (Scholz 2010 and references herein). In geothermal reservoirs, large variations of $b$-values in time and space have for example been observed by Bachmann et al. (2012). They calculated the $b$-value for the time period during injection and after injection. The $b$-values varied from 1.58 during injection to 1.15 after injection, which represents a larger proportion of small earthquakes during injection.

Dorbath et al. (2009) calculated a $b$-value of $>1.2$ for the stimulations of the well GPK2 at Soultz, whereas for the well GPK3, which is a maximum $500 \mathrm{~m}$ away from GPK2, was determined to be 0.9. They related this behavior to the presence of large fault zones in the vicinity of the well, which dominate their seismic evolution.

\section{The Soultz geothermal site}

The European geothermal project of Soultz-sous-Forêts (France) targets a geothermal anomaly at the western border of the Upper Rhine Graben. Five wells have been drilled to a maximum depth of $5 \mathrm{~km}$. Three of these wells are currently used for operation with two wells as injectors (GPK3 and GPK4) and one producing well (GPK2) (Genter, personal communication). The upper geothermal reservoir is hosted by a porphyritic Hercynian monzogranite (Figure 2a), overlain by $1.4 \mathrm{~km}$ of Mesozoic sediments. The lower reservoir lies in fine-grained two-mica granite, which can be encountered at depths greater than $4.6 \mathrm{~km}$. The pluton has been affected by the Upper Rhine Graben tectonics, which caused the formation of large sets of faults and fracture zones. These faults and fractures are the main pathways for circulating fluids and are thus responsible for the permeability of the rock (Genter and Traineau 1992). Paleo-circulation of meteoric fluids from the Graben shoulders led to pronounced alteration of the Soultz granite. The first pervasive alteration affected the whole granitic matrix (Figure 2b) but had no effect on the structural properties of the granite. It involved the formation of mainly chlorite and hematite. A subsequent vein alteration event significantly changed 

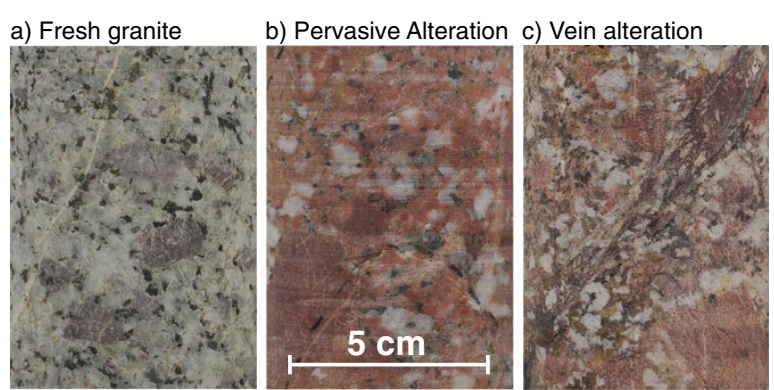

Figure $\mathbf{2}$ Core pictures of different facies of the Soultz granite. (a) Fresh granite without evidence of hydrothermal alteration. (b) Pervasive alteration with mainly formation of hematite and no structural influence. (c) Vein alteration with dissolution of silicates and precipitation of clay minerals.

the granite structure (Figure 2c). During this alteration event, primary minerals were dissolved, and secondary minerals precipitated (Schleicher 2005). Alteration halos developed enfolding the zones around fractures affected by hydrothermal alteration. These halos can be several tens of meters thick and are characterized by the transformation of mainly silicates and the precipitation of secondary clay minerals, quartz, carbonates, sulfates, and iron oxides (Genter and Traineau 1996). The dominating clay minerals of the vein alteration are several generations of illites and smectites, and minor tosudite and chlorite (e.g., Bartier et al. 2008).

The sealing of fractures by secondary minerals and the transformation of silicates into clay minerals affected the hydraulic and mechanical properties of the rock (Valley and Evans 2003; Charléty et al. 2007), whereas the details of such processes are still subject to extensive research. Bartier et al. (2008) highlighted for example the importance of clay mineralogy for the permeability of the Soultz granite, which is reduced by illite precipitation but enhanced by tosudite precipitation. Ledésert et al. (2010) highlighted the complexity of processed linked to porosity/permeability formation and decrease by the dissolution and transformation of primary minerals and the formation of new minerals. The type and structure of clay minerals are not only important for the evolution of porosity and permeability but also for the shearing properties of a fault filled with clays.

The variation of hydro-mechanical properties of the rock with different alteration types and grades makes it important to first detect alteration zones and, second, to understand their significance for the performance of a reservoir (Figure 2).

\section{Methods}

The basis for the rock mechanical studies are neural network-derived synthetic clay content logs (SCCL), which present the clay content along the borehole in a semiquantitative way with five groups of increasing clay content. In sedimentary rocks, clay minerals can be easily identified from peaks in spectral gamma ray (SGR) logs. In crystalline rock in contrast, apart from clays, numerous other minerals contain radioactive isotopes, which makes it difficult to identify clay minerals on SGR logs. Therefore, a neural network is used, which makes it possible to identify different signal patterns on logging data and to localize the clay-bearing zones. The resolution of the resulting SCCLs is on the scale of decimeters. 
The neural network for the creation of the synthetic clay content logs uses a selforganizing map working with a Kohonen algorithm (Kohonen 1984). The principle of this procedure is the grouping and indexing of patterns according to their spatial distance from each other. Each combination of $n$ logs represents a vector in $n$ dimensions. The location of these vectors in $n$ dimensions determines their assignment to the nodes of a two-dimensional self-organizing map. Thus, their dimension is reduced, which makes it easier to classify them. The number of classes can be defined according to the desired resolution. The network is trained using supervised learning, which means the grouping and classification of the nodes based on reference data. These reference data are used to teach the neural network how different parameters are correlated. For this study, the reference data consists of spectral gamma ray logs and a fracture density log. A log representing the density of clay-filled fractures was derived from core investigations of the EPS1 reference well and served as a template for the classification of the nodes. For the deep wells GPK1 to GPK4, the fracture density log could be computed on the basis of fractures identified on borehole image logs. The resulting SCCLs (Figure 3) semi-quantitatively represent the density of clay-filled fractures along the boreholes with five groups. The major flow paths through the granite are marked by dashed lines. Group 1 represents the group with the lowest clay content, and group 5 represents the highest clay content. The comparison with reference data has shown that only approximately $10 \%$ of the logs deviates more than 1 SCCL group from real data and the vertical resolution of the logs is between 10 and $50 \mathrm{~cm}$ depending on the resolution of the SGR logs, from which they are derived.

The SCCLs allow discriminating between zones of high and low clay contents. Whereas the upper parts of all wells are characterized by high SCCL values, representing the paleoalteration surface, the lower parts are very different for the five wells. Intervals with high SCCL are mostly found around fractures, which have been identified as permeable on flow logs, but hydrothermal alteration also occurs away from such fractures. However, not all permeable fractures are located in altered zones. This might be due to the fact that extreme alteration leads to a clogging of fractures with clay minerals, thus reducing its permeability (Sausse 2002). The actually flowing fractures might not have been permeable in the past, which prevented the surrounding rock from being hydrothermally altered. Increased clay content is seen at the bottom of the wells below 4,600 $\mathrm{m}$ at the transition between the porphyritic and the two-mica granite. For details of this neural network method, the SCCLs, and the calibration of the logs by magnetic mineralogical investigations refer to Meller et al. (2014a; 2014b) (Figure 3).

For the deep wells in Soultz, no core material is available. Therefore, petrophysical and geologic parameters can only be derived from borehole measurements and seismicity catalogs. This study is mainly based on breakout and fracture analyses conducted on borehole image logs and on a catalog of seismic events recorded during hydraulic stimulation. Borehole breakouts are enlargements and elongations of a borehole in a preferential direction and are formed by spalling of fragments of the wellbore during drilling. They generally form parallel to minimum horizontal stress, and their formation is facilitated in weak wall rocks (Babcock 1978). Their analysis can therefore provide information about the orientation of the stress field and on the mechanical properties of the penetrated rock. Seismic events induced during stimulation are an indication of structures in the geothermal reservoir. Their analysis provides indications about the stress state, fracture orientation, rock mechanics, and fluid pathways. 


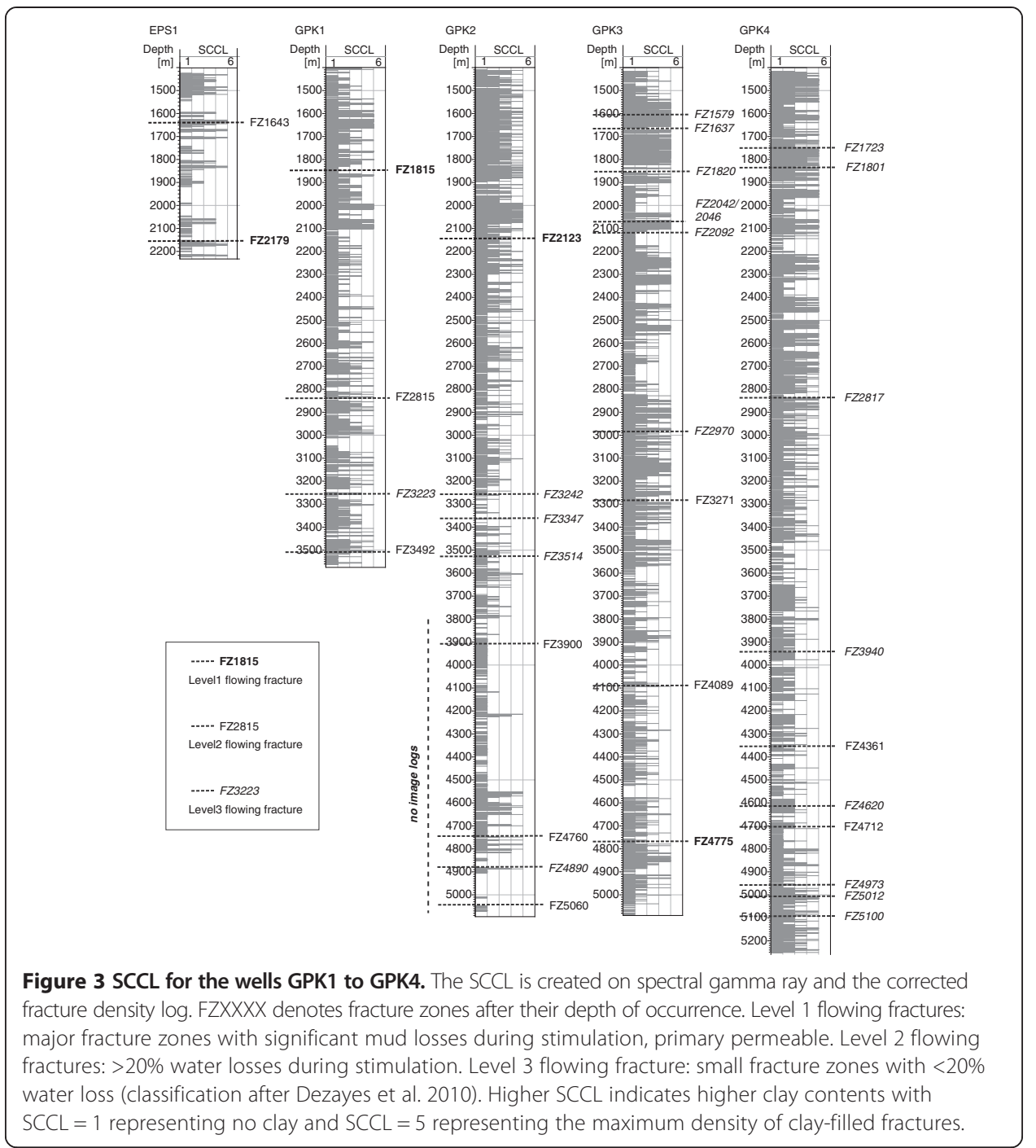

\section{Results and discussion}

\section{Impacts of hydrothermal alteration on rock mechanics}

Due to their preferential formation in weak rocks, a cumulative occurrence of breakouts in altered zones in the Soultz granite could be indicative of the weakness of alteration zones. This theory was investigated on the basis of breakouts, identified by Sahara et al. (2014). They analyzed breakouts in the deeper part of the well GPK4. On Figure 4, a total of 2,440 breakouts from Sahara et al. (2014) together with the SCCL for this depth interval are illustrated. A correlation between clay content and the appearance and size of the breakouts is obvious. Whereas the density of breakouts is high in clay-rich intervals, depth sections without clay are characterized by an absence of breakouts, as for example at $4,180,4,480$ to 4,590 , and 4,730 to $4,800 \mathrm{~m}$ (BA in Figure 4). Obviously, the occurrence of breakouts is strongly related to the presence of hydrothermally altered zones. This suggests that hydrothermal alteration weakens the rock and thus promotes the formation of breakouts. Upon the transition from the porphyritic granite to the two-mica granite at around $4,800 \mathrm{~m}$, the breakout density 


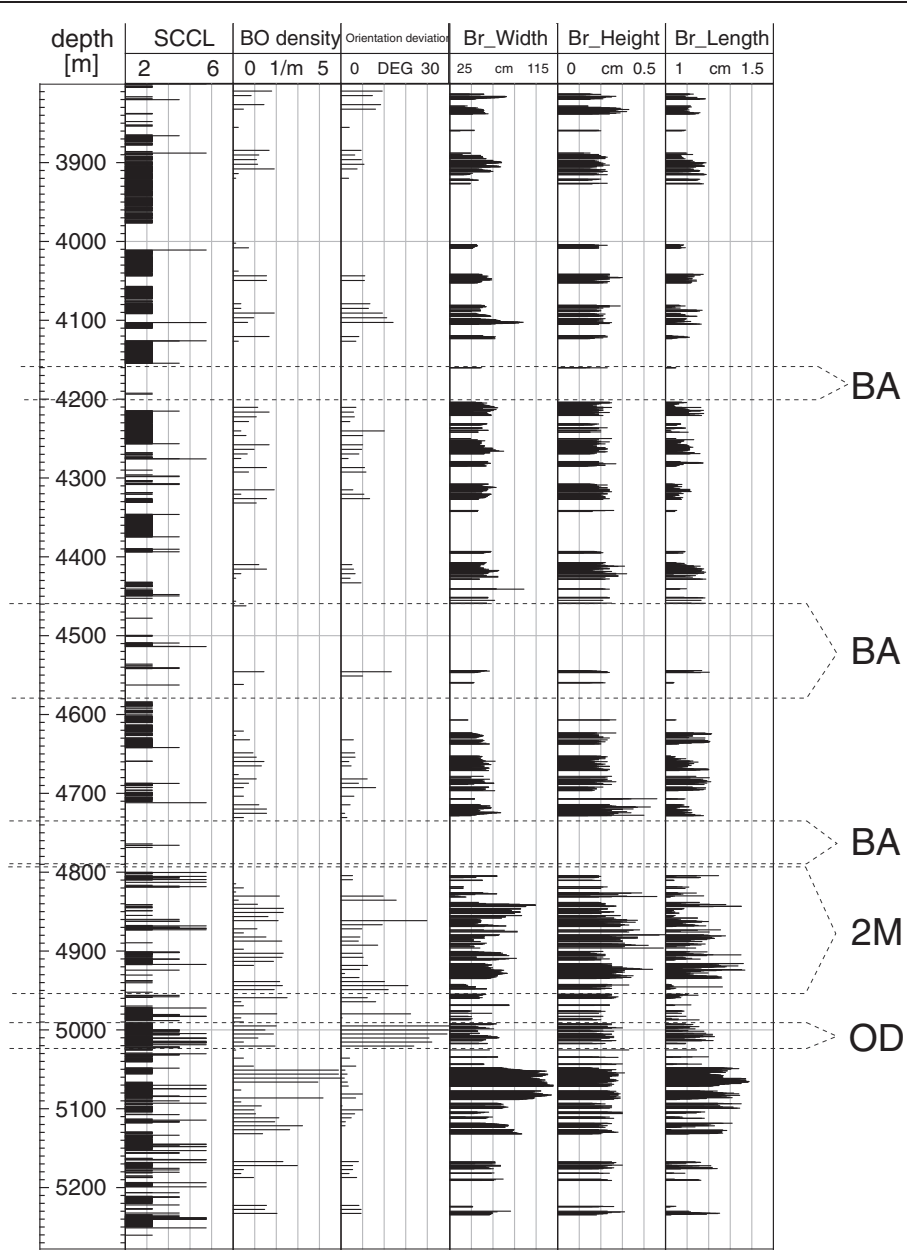

Figure 4 SCCL 2 to 5 of the well GPK4 compared to the breakout density, orientation deviation, and breakout dimensions. There is a clear correspondence between breakout appearance and size and the SCCL (breakout data from Sahara, personal communication). Intervals without clay are characterized by an absence of breakouts (BA). On the transition between standard granite and two-mica granite at around $4,800 \mathrm{~m}$, the orientation of the breakout changes (2M). This might be attributed to the mechanical contrast between the two granitic rock masses. A clay-rich interval around 5,000 m depth coincides with a large orientation deviation of the breakouts (OD).

clearly increases (2M in Figure 4). The cumulated occurrence of breakouts at this transition might originate from the mechanical contrast between the two granites. Such mechanical contrast occurs also at the transition between fresh granite and strongly altered granite.

The correlation of the clay zones with the occurrence of breakouts demonstrates their geomechanical significance. However, it is in contrast to present studies, which seem to identify rather high friction coefficients for the Soultz granite. By applying the Mohr-Coulomb failure criterion using effective stresses on the fractures, Cornet et al. (2007) obtained a minimum friction coefficient of 0.81. Evans et al. (2005a) found that fractures in highly altered zones are surprisingly strong despite the presence of illite and ascribed this behavior to their internal architecture of intact rock bridges and jogs between weak zones. According to Byerlee (1978), rock samples with precut fault surfaces have a uniform friction coefficient of 0.85 and no cohesion at normal stress below $300 \mathrm{MPa}$, independent from the rock type. However, Byerlee (1978) observed that 
fractures filled with clay minerals are an exception from his law and have much lower friction coefficients. A gradual decrease in frictional strength with the addition of clay has also been observed in triaxial measurements of the Berea sandstone under high temperature and high pressure conditions. Here, a sharp drop of the friction coefficient occurred at clay contents of approximately 50\% (Takahashi et al. 2007). In these experiments, clay minerals inside fractures were observed not only to weaken faults but also to stabilize their sliding behavior. Crawford et al. (2008) performed experiments of quartz-kaolinite mixtures of different proportions and compared their strength. They also observed a reduction of frictional strength with an increasing clay fraction. Ikari et al. (2009) obtained low friction coefficients of fault gouges rich in phyllosilicates (Figure 5).

These experimental results are in agreement with the breakout observations at Soultz, which indicate weakness of the hydrothermally altered zones, but which are in contrast to the high minimum friction coefficient of 0.81 determined by Cornet et al. (2007) for the whole granitic rock mass. It is therefore assumed that hydrothermal alteration causes a variation in the frictional properties of the Soultz granite on a meter scale with higher frictional strength in unaltered rock and a lower frictional strength in altered rock.

Elastic properties of the Soultz granite have been experimentally studied by Valley and Evans (2003). They selected samples of different alteration grades from the EPS1 core and measured the uniaxial compressive strength (UCS) of the core pieces. Furthermore, they measured the S- and P-wave velocities of the samples in order to determine their $E$-moduli. They found an inverse correlation between alteration grade and UCS and the $E$-modulus of the samples (Figure 5). From the results of this study, it is expected that the highly altered clay zones affect the frictional properties in Soultz and the friction coefficient is not uniform but is lowered by hydrothermal alteration.

Recent researches showed that a characteristic of such weak zones is that they can fail at low stress levels, as it is for example observed on a large scale on the San Andreas Fault in a strike slip regime, whose slip direction deviates $70^{\circ}$ from the maximum horizontal stress (e.g., Boness and Zoback 2006), the Zuccale normal fault on Elba (e.g., Smith et al. 2007) or some normal faults at the eastern side of the Sea of Japan (e.g., Sibson 2009; Faulkner et al. 2010). If such observations can be transferred to the reservoir scale, hydrothermally altered zones might fail at lower stress levels than the surrounding intact rock mass. This is especially important in terms of hydraulic stimulation, as weak faults could shear at much lower stimulation pressure than unaltered rock and influence the evolution of induced seismicity (Figure 4).

\section{Impacts of hydrothermal alteration on the stress field}

Clay layers inside rock masses give rise to large contrasts of mechanical properties. In contrast to intact crystalline or sedimentary rock masses, weak clay-rich zones cannot establish large differential stress (Zoback and Harjes 1997).

The stress field in Soultz has been thoroughly investigated by many scientists (Valley and Evans 2010; Cornet et al. 2007; Rummel 1995, and references herein). This resulted in detailed knowledge of the magnitude and orientation of the principal stress components with depth. Based on the analysis of wellbore failure and hydraulic data as well as 


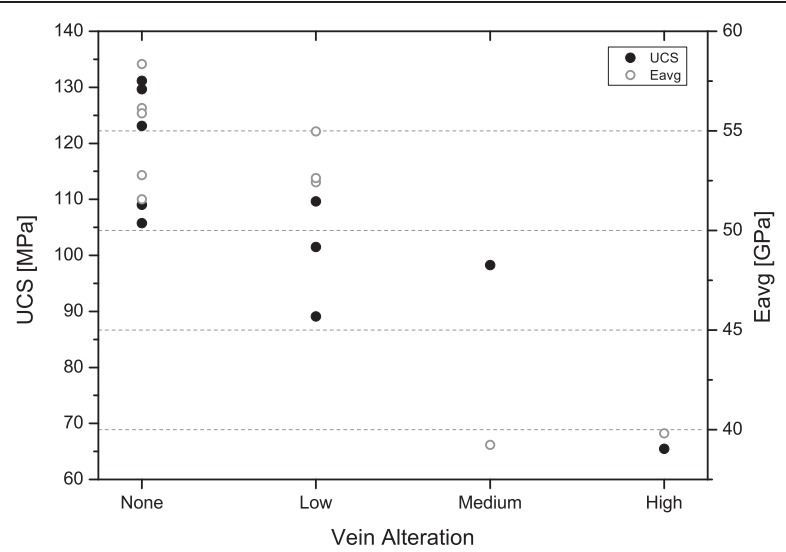

Figure 5 E-moduli and uniaxial compressive strength (UCS) of samples with different vein alteration grades. Data is taken from Valley and Evans (2003) who measured UCS and E-modulus for samples with different alteration grades. Alteration intensity is inversely correlated with E-modulus and UCS.

microseismic data, a linear stress model has been established for the Soultz reservoir (Valley and Evans 2007; Cornet et al. 2007)

$$
\begin{aligned}
& S_{\mathrm{v}}=-1.3+0.255 z \\
& S_{\mathrm{H}}=0.98(-1.3+0.255 z) \\
& S_{\mathrm{h}}=-1.78+0.01409 z \\
& P_{\mathrm{p}}=0.9+0.0098 z
\end{aligned}
$$

with $P_{\mathrm{p}}$ the pore pressure and $z$ the depth in meters.

The $S_{\mathrm{H}}$ orientation is approximately north-south, and the vertical stress $S_{\mathrm{V}}$ is equivalent to the overburden. However, in inhomogeneous rock masses with changing mechanical properties, the magnitude and orientation of the stress field change at the transition between layers of different mechanical strength. The Soultz granite is very heterogeneous due to its porphyritic structure, its lithological variations, hydrothermally altered zones, and the profound fracturing. Borehole breakouts generally form in the direction of the minimum horizontal stress and are therefore useful indicators of the orientation of $S_{\mathrm{h}}$ and $S_{\mathrm{H}}$. An analysis of borehole breakouts can give evidence about local stress variations. The high resolution of the SCCLs in the order of decimeters for the first time allows a detailed analysis of the indications for stress field variations at Soultz on the basis of breakouts. In the following section, the occurrence of breakouts and their orientation is interpreted on the basis of the SCCLs.

Evidence for a change in the direction of the principal stresses can be found in breakout data from Sahara et al. (2014) in the well GPK4. The transition from porphyritic to two-mica granite at around 4,800 $\mathrm{m}$ ( $2 \mathrm{M}$ in Figure 4$)$ is not only characterized by an increased breakout density but also by a deviation of the mean breakout orientation. As breakouts generally form in the direction of the minimum principal stress, an orientation deviation of the breakout could be an indicator for a rotation of $S_{\mathrm{h}}$. Another excursion of the breakout orientation is observed at a depth of 5,000 m (OD in Figure 4). This deviation coincides with a very clay-rich interval. This clay-rich interval might act as a small stress-decoupling horizon, which rotates the principal stress. According to the data of Sahara et al. (2014), stress rotations in clay-rich intervals can be as large as $\pm 30^{\circ}$ from the mean orientation. Deviations of breakout orientations in 
hydrothermally altered zones have also been observed by Valley (2007) in the wells GPK3 and GPK4. He observed major stress perturbations occurring at depths of 2,000 and 4,700 m. The SCCLs show that these stress perturbations coincide with the occurrence of clay-rich intervals related to large-flowing fracture zones (FZ2123, FZ4760, FZ4775, Figure 3), but it cannot be ruled out that they could also be caused by the presence of the fracture zones as it was, for example, observed by Valley (2007). The stress variation at approximately $4,700 \mathrm{~m}$ is probably caused by the contrast in the elastic moduli of the rock between the standard porphyritic granite and the two-mica granite at this depth and the increased clay content (Figure 6).

Valley and Evans (2000) analyzing breakouts in the well GPK1 between 2,840 and $3,510 \mathrm{~m}$ found an increased breakout concentration at the top of this interval. This agrees with the occurrence of a clay-rich interval in this section indicated by high SCCL (Figure 6). The mean $S_{\mathrm{H}}$ orientation determined from breakouts is $0^{\circ} \pm 19^{\circ}$, which is in agreement with the mean orientation of the structures of the microseismic cloud. Excursions of the mean breakout orientation occur in the intervals 2,890 to 2,950 and 3,300 to 3,350 $\mathrm{m}$, which are characterized by high SCCL values. The occurrence of breakouts in GPK1 between 2,960 and 3,500 $\mathrm{m}$ is not only restricted to high-clay zones but high breakout-densities as, for example, at 3,000 to $3,050 \mathrm{~m}$ or at 3,400 to $3,450 \mathrm{~m}$ depth also occur, when a depth interval without or with very little clay is followed by a very clay-rich interval. Here, the contrast of elastic moduli of the two depth intervals might cause a cumulating appearance of breakouts. This might also be represented in the different orientations of the microseismic cloud in the depth intervals 2,700 to $2,900 \mathrm{~m}$, where it is oriented north-south, and 3,200 to 3,600 m, where its azimuth is $145^{\circ}$ to $160^{\circ}$ (Cornet et al. 1997). Cornet and his colleagues (1997) linked this orientation deviation to the higher pore pressure above 2,900 $\mathrm{m}$, but it could also be related to the presence of clay-rich zones. Such clay-rich zones could also lead to increased pore pressures (Wu 1978).

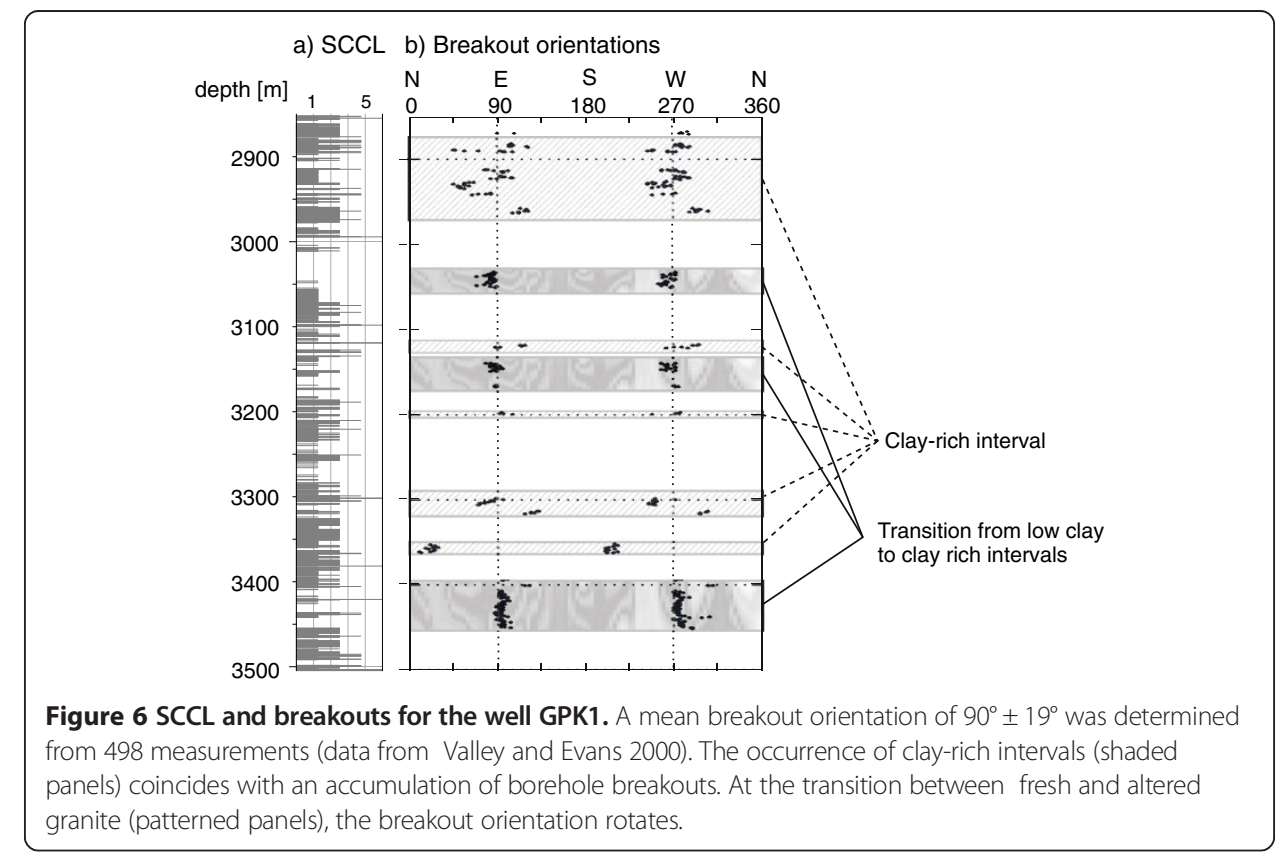


Similar analyses have been conducted by Langenbruch and Shapiro (2014) who investigated stress states in boreholes from different regimes. Based on sonic logs, they created a model of the in situ elastic moduli to calculate the spatial distribution of in situ stress within a rock mass. Their large spatial variations of the stress regime suggest that linear stress models are not sufficient for Coulomb failure within a rock mass. Economides et al. (1989) observed that within sedimentary formations, the vertical gradient of the minimum horizontal principal stress does not vary linearly with depth. The authors found that elastic heterogeneity has a significant influence on stress magnitudes, which vary by up to more than $\pm 20 \%$ of the externally applied stresses. Cornet and Roeckel (2012) observed this phenomenon in limestone layers of the Paris Basin and in the North German Basin. They saw that the local stress magnitudes are not linearly increasing with depth, and they saw variations of approximately $15^{\circ}$ in the stress directions. In contrast to Langenbruch and Shapiro (2014) and Economides et al. (1989), they assume that the stress magnitudes are controlled by the creeping characteristics of the various layers rather than by their elastic characteristics (Cornet and Roeckel 2012).

The change of the local stress field in magnitude and orientation has previously been described for large fracture zones (e.g., Brudy et al. 1997). In the San Andreas Fault, for example, a stress rotation of approximately $28^{\circ}$ with respect to the stress field of the rigid crust has been measured (Chéry et al. 2004). Cornet and Roeckel (2012) identified soft layers as decoupling layers introducing decoupling of stress fields in the layers above and below these layers. This was also observed by Meixner et al. (2014) who documented a rotation of the maximum horizontal stress in different facies along the Bruchsal geothermal wells (c.f. Figure seven in his article).

However, in those studies, stress field variations are only observed on large scales of several kilometers. The analysis of breakouts on the basis of SCCLs provides indications that changes of the stress field both in magnitude and orientation of the principal stress can also be induced by small-scale soft alteration zones on the meter scale as observed in geothermal wells. Taking these observations into account, it is obvious that the estimation of mechanical properties on the basis of a linear stress field can only provide far field values, especially for zones, where the SCCL is high. So, in addition to the frictional parameters, the exact orientation of the stress field has to be constrained in hydrothermally altered zones in order to be able to assess their mechanical characteristics.

\section{The impacts of hydrothermal alteration on induced seismicity}

At Soultz, 20 hydraulic and chemical stimulations have been performed and large catalogs of seismic events are available (Genter et al. 2010). During hydraulic stimulation, large amounts of water are injected into the geothermal reservoir in order to increase the pore pressure prevailing in the reservoir rock. If the pressure increase is large enough to overcome the frictional stability of fractures, shear movements are induced, which can be observed by the occurrence of microseismic events. A detailed summary of the background of hydraulic stimulation can, for example, be found in Economides et al. (1989) or Majer et al. (2007).

The parameters influencing the evolution of induced seismicity like the pressure of the fluid, the ambient stress field, the orientation of fractures, hydraulic properties, and the frictional characteristic of rock can be affected by hydrothermal alteration. Herein, 
the relation between hydrothermal alteration and induced seismicity at Soultz is investigated.

Except for some new fractures, which are created during hydraulic stimulation at Soultz by hydrofracturing (Cornet 2012), seismicity in the Soultz reservoir is mainly restricted to shear movements on existing geological structures, which can be observed during all stimulations performed on the Soultz wells (e.g., Evans et al. 2005b; Fabriol et al. 1994; Dorbath et al. 2009). However, it is not clear why some structures are seismically more active than others. According to the Mohr-Coulomb failure criterion, the most important factor affecting the shearing behavior of a fracture or fault is its orientation relative to the ambient stress field. Favorably oriented fractures lie (sub)-parallel to the maximum principal stresses and can thus be easily sheared. The focal mechanisms at Soultz (cf. Figure one in Schoenball et al. 2012) indicate that some fractures produce seismic events upon hydraulic stimulation unless they should be stable according to the Mohr-Coulomb failure criterion. A possible reason for that could be a very low shear strength of some fractures, which allows them to shear at large angles to the maximum stress. This gives further evidence that the friction coefficient of fractures at Soultz is not homogeneous but rather varies in a wide range (Figure 7).

Aseismic movements on fractures have been directly observed in Soultz by Cornet et al. (1997). The SCCL of GPK1 indicates clay-rich intervals between 2,800 and 3,000, 3,050 and 3,100, 3,180 and 3,230, 3,340 and 3,410, and 3,450 and 3,500 $\mathrm{m}$ (Figure 7). The stars in this figure mark the shear movements, which have been induced during stimulation of GPK1, and which have been identified on image logs. All shear zones lay close to the flowing zones inside hydrothermally altered intervals, whereas most of the shear movements were aseismic (yellow stars). The higher number of aseismic movements at shallower depths is most probably related to the higher density of (large) fractures. A comparison between the orientation of these fractures and the orientation of $S_{\mathrm{H}}$ (Figure 8) reveals that some of the creeping fractures strike at an angle of $>30^{\circ}$ to $S_{\mathrm{H}}$. If the Mohr-Coulomb failure criterion accounts for these fractures, their friction coefficients must be very low that shear is induced under the present conditions.

The correlation of aseismic movements with clay-rich intervals and their orientation at a significant angle to $S_{\mathrm{H}}$ supports the assumption of clay acting as some kind of lubricant on the fault zones. This makes these fractures prone for aseismic shearing, although they are not optimally oriented in the present stress field. Aseismic movements are assumed to take a big share of the movements induced during hydraulic stimulation, and some authors even assume that the major part of shearing happens aseismically (e.g., Schoenball et al. 2014; Bourouis and Bernard 2007). Further evidence for aseismic movements in Soultz in GPK1 (Bourouis and Bernard 2007; Schmittbuhl et al. 2013; Schmittbuhl et al. 2014), GPK2 (Schoenball et al. 2014; Calò et al. 2011), and GPK3 (Calò et al. 2011; Nami et al. 2008) underlines the significance of clay on the structural reservoir evolution of the reservoir (Figure 8).

The SCCLs provide a unique opportunity to investigate the relation between seismic events and clay inside the reservoir. It is best constrained by calibration in the wells GPK1 and GPK3. In GPK2, the quality of the SCCL is bad due to the lack of logging data SCCL, and for GPK4, the location uncertainty of seismicity is too large (Gaucher, personal communication). Therefore, the analysis is focused on GPK1 and GPK3. In the well GPK1, the location and magnitude for several 19,000 seismic events have been 


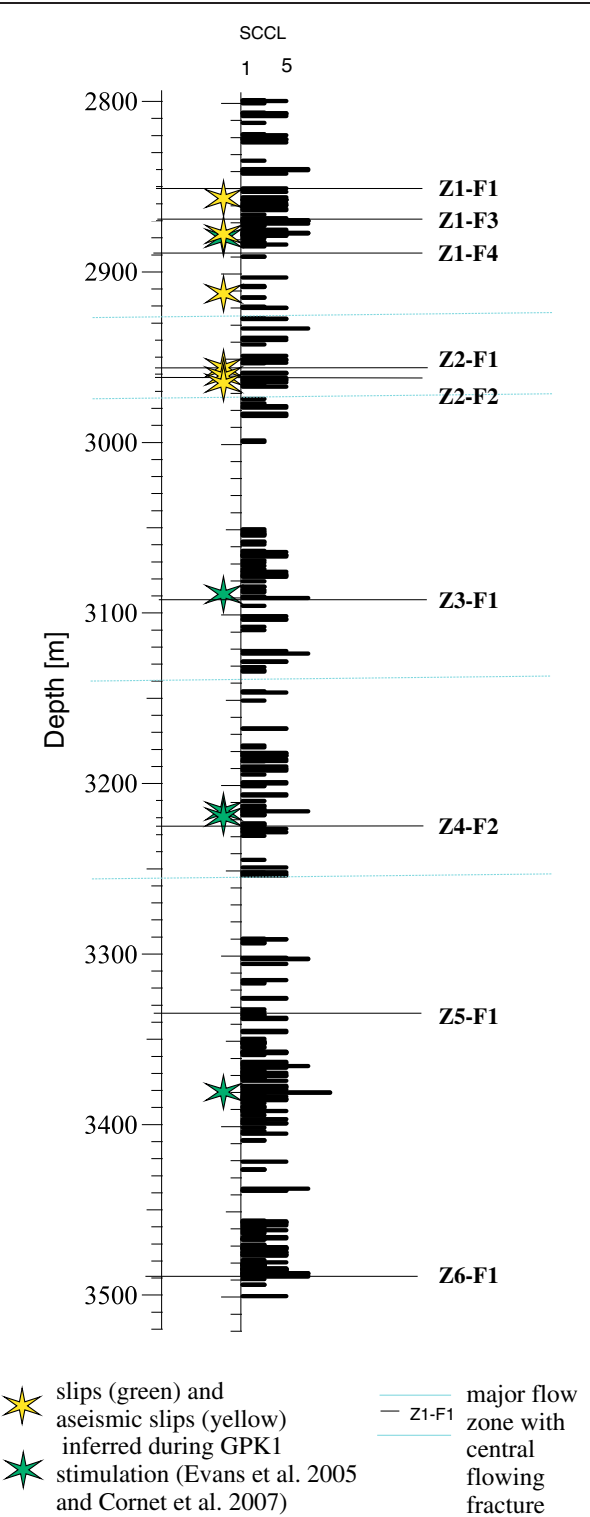

Figure $7 \mathrm{SCCL}$, major flow zones, and the occurrence of aseismic fault slip. In the well GPK1 between 2,800 and 3,500 m. SCCL and the location of (aseismic) slips during GPK1 stimulation have been identified by Cornet et al. (1997) and Evans et al. (2005a). Major flow zones are surrounded by zones of high SCCL. Slip is restricted to hydrothermally altered clay zones with high SCCL. The occurrence of aseismic slips is restricted to clay-rich flowing faults.

determined (Jones et al. 1995), and for GPK3, 22,000 events have been located (Dyer et al. 2003; Dorbath et al. 2009). As the SCCLs can only indicate clay in the proximity of the wells, the events in a radius of $100 \mathrm{~m}$ around the borehole are selected. For the remaining 5,600 events (4,200 for GPK1 and 1,400 for GPK3), the respective SCCL value of the depth, where they occurred, is determined. Then, the magnitude of the respective event is plotted against the SCCL value (Figure 9). The exciting result of this plot is that with increasing clay content, the maximum magnitude of seismic events is decreasing. Recent observations of Schorlemmer et al. (2005), Langenbruch and Shapiro (2014), and others suggest that low differential stress in weak zones prevents large seismic events, and it has long been assumed that the occurrence of large events in Soultz is restricted to fresh, i.e., 


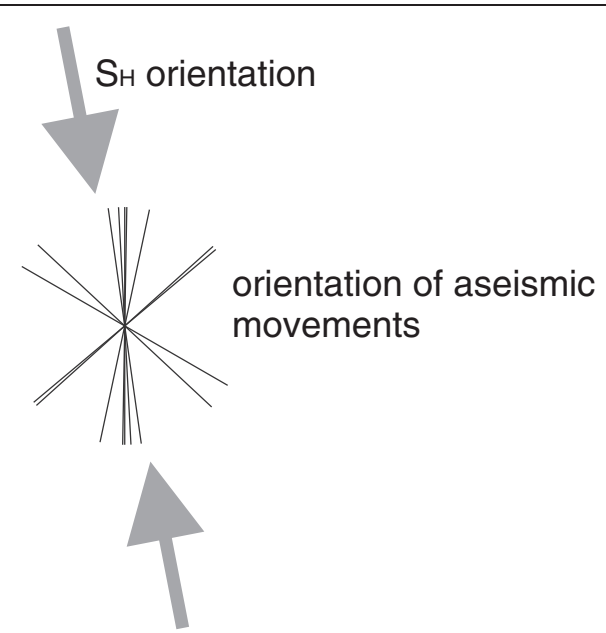

Figure 8 Strike of the aseismic movements observed by Cornet et al. (1997) versus the orientation of $S_{\mathrm{H}}$. Some of the aseismic movements happened on fractures, which are oriented at an angle $>30^{\circ}$ to $S_{H}$, which indicates weakness of these fractures, as they are not favorably oriented for shear.

unaltered granite, but it could never be directly observed. This figure suggests that the $b$-value of Soultz, although not constant in time, is also affected by the occurrence of hydrothermally altered zones. The $b$-value of the entire 2,000 stimulation test of GPK2 was determined to be 1.29 by Cuenot et al. (2008), and for the GPK3 stimulation, Dorbath et al. (2009) determined a $b$-value of 0.94 . It would be interesting to compare the total clay content in both wells in order to find a correlation between the total clay content and the $b$-value. Unfortunately, the SCCL of the lower part of GPK2 could not be properly created due to missing image logs. The rather large value of 1.29 for GPK3 might be indicative of weak structures as such high values are normally only found in regions of crustal weakness (Amitrano 2003).

Therefore, the presence of large faults is most probably not the only reason for the different seismic behaviors of GPK2 and GPK3 as it was observed by Dorbath et al.

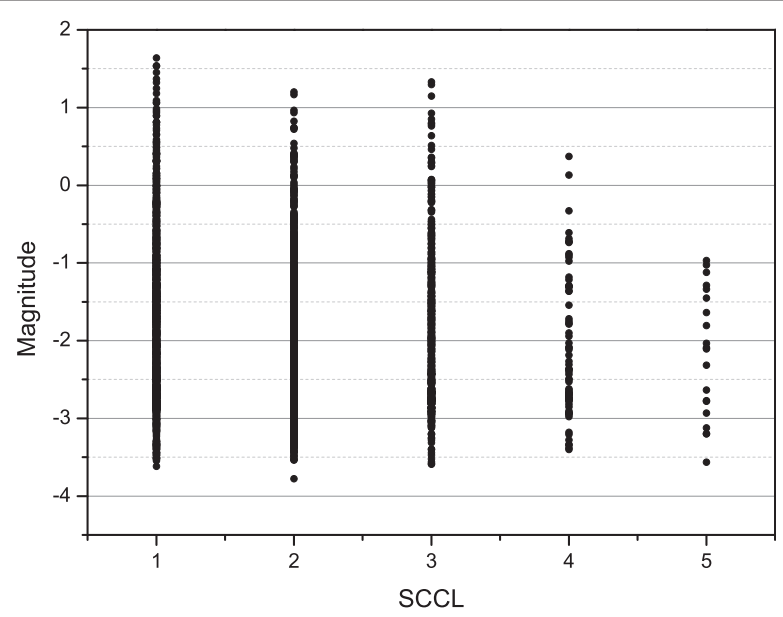

Figure 9 SCCL versus magnitude of induced seismic events during GPK1 and GPK3 stimulation. Seismic events with large magnitudes are restricted to low SCCL values, i.e., intervals with little clay inside fractures. With increasing clay content (higher $\mathrm{SCCL}$ ), the maximum magnitudes of seismic events are smaller. 
(2009). The different $b$-values, which can be obtained from the seismic events induced during stimulation of these wells, could also be affected by the presence/absence of alteration zones (Figure 9).
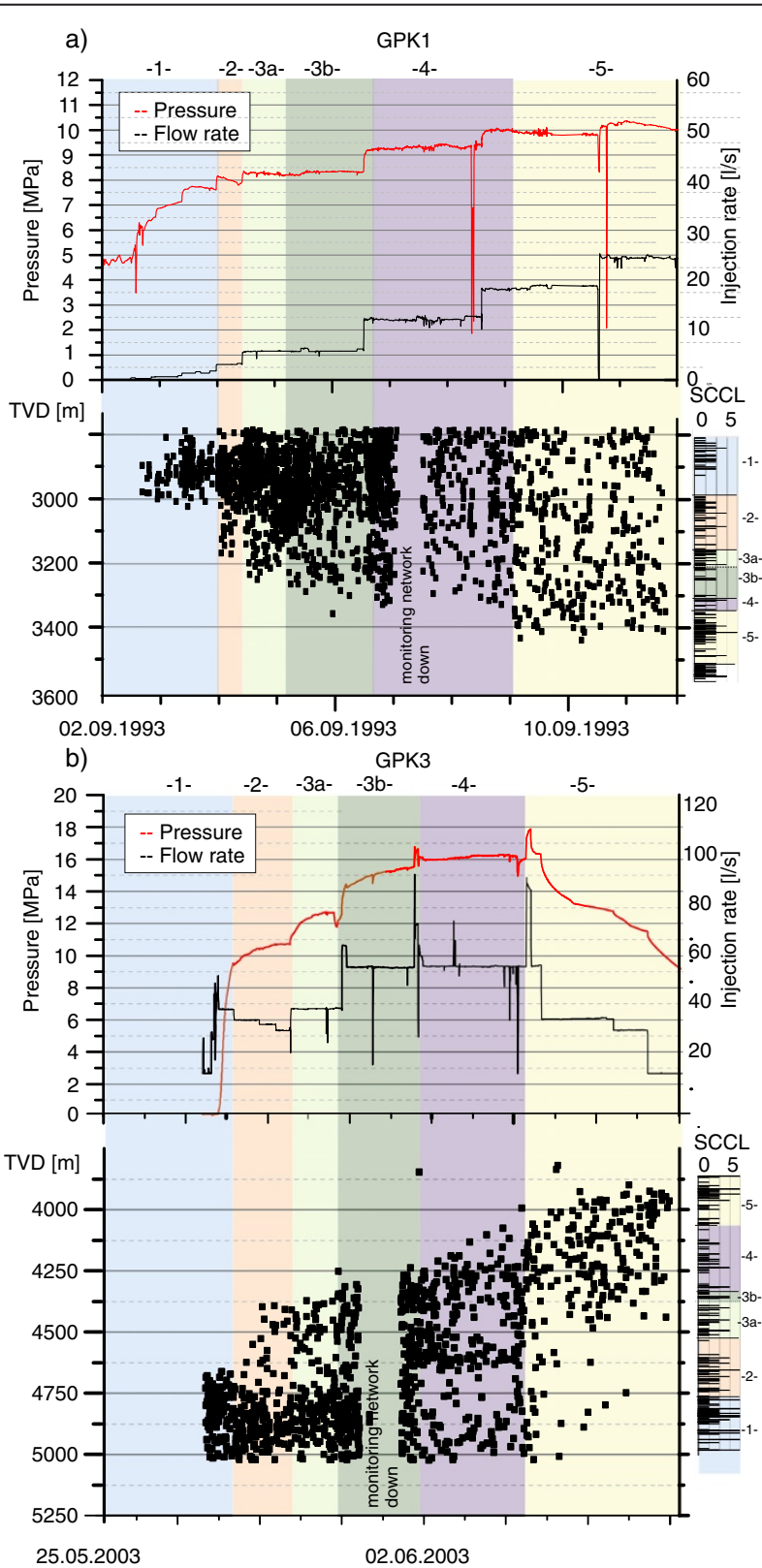

Figure 10 Evolution of seismicity in a radius of $100 \mathrm{~m}$ around the boreholes during stimulation and SCCL. The upper part of the diagrams show the stimulation pressure and below, the time-evolution of induced seismicity is shown versus depth. The lower part of the diagrams shows the SCCL for the respective depth intervals. Different sections are marked by numbers and colors indicating the pressure steps of injection. With increasing stimulation pressure, seismicity migrates downwards for (a) GPK1 and upwards for (b) GPK3. The steps might be caused by clay-rich intervals, which rather promote creep than seismic shearing. After each pressure increase, seismicity begins at depths, where the clay-content is low until the pressure front reaches a clay-rich interval. This interval is overcome during the next pressure increase, and seismicity starts just after the clay-rich zone migrating towards the next clay-rich zone, and so on. From step 5 on, we assume that the pressure front migrated too far away from the borehole so that a correlation with the (two-dimensional) SCCL is not possible any more. 
There is evidence that hydrothermally altered zones not only affect the magnitude but also the evolution of seismicity. The seismic clouds of the GPK1 and GPK3 stimulation move downhole or uphole in steps, when the injection pressure is increased (Figure 10). Each pressure increase is marked by colored rectangles in Figure 10. The SCCLs provide a possible explanation of the reason of these steps. Each of these steps starts with a clayrich zone and ends with an interval with little clay. As mentioned before, clay-rich intervals do not support large stresses and could act as small stress-decoupling horizons as observed by Cornet and Roeckel (2012) in the Paris Basin. They might therefore prevent the occurrence of seismic events or shear movements, or the events in such zones are very low-magnitude events, thus being too small to be measured, i.e., those slips are aseismic. With each pressure increase, the pressure front penetrates the decoupling horizon without inducing seismicity and the seismic events start just below or above this zone, migrating upward (as in GPK3, Figure 10b) or downward (as in GPK1, Figure 10a) until the next clay-rich zone is reached. This interval will then be overcome by the next pressure increase and so on, leading to a stepwise migration of microseismicity (Figure 10).

\section{Conclusions}

The present SCCL method is an important basis to localize clay-rich zones as target zones for hydraulic stimulation and to identify fractures as candidates for aseismic movements. In order to optimally use the properties of hydrothermally altered zones, further effort has to be done on understanding of the processes affecting the geomechanical behavior of a geothermal reservoir. Once such processes are understood, it might become possible to exploit the properties of altered zones in order to increase the reservoir performance, while mitigating perceptible seismicity.

The occurrence of hydrothermally altered zones inside a geothermal reservoir can have large effects on many physical aspects, which are important for the performance of a geothermal system, and especially those related to induced seismicity. The observations at Soultz-sous-Forêts revealed that hydrothermal alteration lowers the mechanical strength of the Soultz granite and its fractures, which results in an inhomogeneously distributed friction coefficient. Geological units with low mechanical strength promote the occurrence of breakouts and can rotate the stress field as much as $90^{\circ}$ from the mean orientation, which is indicated by high breakout-densities in clay-rich intervals and a deviation of their mean orientation.

A major result of this study is that hydrothermally altered zones can act as decoupling horizons, which change the local stress regime and thus significantly affect the seismicity induced during hydraulic stimulation at Soultz. It has been shown that large seismic events are restricted to fresh granite, whereas only small seismic events occur in clay-rich intervals. While this behavior has often been observed on the crustal scale, the present study for the first time confirms this effect on the scale of a geothermal reservoir.

Due to their low frictional strength and increased pore pressures, hydrothermally altered zones represent major target zones for hydraulic stimulation. In the future, EGS projects need to be structured in that prevention of large seismic events becomes a major achievement. Future stimulations could foster the creation of aseismic instead of seismic slip to increase the reservoir permeability, which requires knowledge on the location of such zones and advanced research towards the evolution of aseismic movements. 


\section{Competing interests}

The authors declare that there are no competing interests.

\section{Authors' contributions}

CM interpreted the SCCL logs on the basis of borehole breakout analyses by Sahara et al. [2014] and of the thesis of Valley [2000] and on borehole analyses mainly conducted by Evans [2005], Evans et al. [2005a; 2005b] and Cornet et al. [1997]. Basis for the analysis were the seismic catalogues of GPK1 Jones et al. [1995] and GPK3 Dorbath et al. [2009]. CM wrote the manuscript and TK conducted the final revision. All authors read and approved the final manuscript.

\section{Acknowledgements}

This research was conducted within the portfolio topic GEOENERGIE of the Helmholtz Association of German Research Centres and was funded by Energie Baden-Wuerttemberg (EnBW), Germany. Thanks are given to GEIE Exploitation minière de la chaleur for providing the Soultz borehole data.

Received: 12 June 2014 Accepted: 11 September 2014

\section{Published online: 16 October 2014}

\section{References}

Akayuli C, Ofosu B, Nyako SO, Kwabena OO (2013) The influence of observed clay content on shear strength and compressibility of residual sandy soils. Int J Eng Res Appl 3(4):2538-2542

Amelung F, King G (1997) Earthquake scaling laws for creeping and non-creeping faults. Geophys Res Lett 24(5):507-510, doi:10.1029/97gl00287

Amitrano D (2003) Brittle-ductile transition and associated seismicity: experimental and numerical studies and relationship with the b value. J Geophys Res Solid Earth 108(B1):2044, doi:10.1029/2001jb000680

Babcock EA (1978) Measurement of subsurface fractures from dipmeter logs. AAPG Bull 62(7):15

Bachmann CE, Wiemer S, Goertz-Allmann BP, Mena B, Catalli F (2012) Why geothermal energy research needs statistical seismology. In: Thirty-seventh workshop on geothermal reservoir engineering. Stanford University, Stanford, California, p 8

Bartier D, Ledésert B, Clauer N, Meunier A, Liewig N, Morvan G, Addad A (2008) Hydrothermal alteration of the Soultzsous-Forêts granite (hot fractured rock geothermal exchanger) into a tosudite and illite assemblage. Eur J Mineral 20:131-142, doi:10.1127/0935-1221/2008/0020-1787

Boness NL, Zoback MD (2006) A multiscale study of the mechanisms controlling shear velocity anisotropy in the San Andreas Fault Observatory at Depth. Geophysics 71(5):F131-F146, doi:10.1190/1.2231107

Bourouis S, Bernard P (2007) Evidence for coupled seismic and aseismic fault slip during water injection in the geothermal site of Soultz (France), and implications for seismogenic transients. Geophys J Int 169(2):723-732, doi:10.1111/j.1365-246X.2006.03325.x

Brudy M, Zoback MD, Fuchs K, Rummel F, Baumgartner J (1997) Estimation of the complete stress tensor to $8 \mathrm{~km}$ depth in the KTB scientific drill holes: implications for crustal strength. J Geophys Res Solid Earth 102(B8):18453-18475, doi:10.1029/96jb02942

Brune JN (1968) Seismic moment, seismicity, and rate of slip along major fault zones. J Geophys Res 73(2):777-784, doi:10.1029/JB073i002p00777

Byerlee JD (1978) Friction of rocks. Pure Appl Geophys 116(4):615-626, doi:10.1007/bf00876528

Calò M, Dorbath C, Cornet FH, Cuenot N (2011) Large-scale aseismic motion identified through 4-D P-wave tomography. Geophys J Int 186(3):1295-1314, doi:10.1111/j.1365-246X.2011.05108.x

Chang S-H, Avouac J-P, Barbot S, Lee J-C (2013) Spatially variable fault friction derived from dynamic modeling of aseismic afterslip due to the 2004 Parkfield earthquake. J Geophys Res Solid Earth 118(7):3431-3447, doi:10.1002/jgrb.50231

Charléty J, Cuenot N, Dorbath L, Dorbath C, Haessler H, Frogneux M (2007) Large earthquakes during hydraulic stimulations at the geothermal site of Soultz-sous-Forêts. Int J Rock Mechanics Mining Sci 44(8):1091-1105, doi:10.1016/j.j.jrmms.2007.06.003

Chéry J, Zoback MD, Hickman S (2004) A mechanical model of the San Andreas fault and SAFOD Pilot Hole stress measurements. Geophys Res Lett 31(15):L15S13, doi:10.1029/2004g|019521

Cornet FH (2012) The relationship between seismic and aseismic motions induced by forced fluid injections. Hydrogeol J 20(8):1463-1466, doi:10.1007/s10040-012-0901-z

Cornet FH, Roeckel T (2012) Vertical stress profiles and the significance of "stress decoupling". Tectonophysics 581:13, doi:10.1016/j.tecto.2012.01.020

Cornet FH, Helm J, Pointrenaud H, Etchecopar A (1997) Seismic and aseismic slips induced by large-scale fluid injections. Pure Appl Geophys 150(3):563-583, doi:10.1007/s000240050093

Cornet FH, Bérard T, Bourouis S (2007) How close to failure is a granite rock mass at a $5 \mathrm{~km}$ depth? Int I Rock Mechanics Mining Sci 44(1):47-66, doi:10.1016/j.jirmms.2006.04.008

Crawford BR, Faulkner DR, Rutter EH (2008) Strength, porosity, and permeability development during hydrostatic and shear loading of synthetic quartz-clay fault gouge. J Geophys Res Solid Earth 113(B3), B03207, doi:10.1029/2006jb004634

Cuenot N, Dorbath C, Dorbath L (2008) Analysis of the microseismicity induced by fluid injections at the EGS site of Soultz-sous-Forêts (Alsace, France): implications for the characterization of the geothermal reservoir properties. Pure Appl Geophys 165(5):797-828, doi:10.1007/s00024-008-0335-7

Dezayes C, Genter A, Valley B (2010) Structure of the low permeable naturally fractured geothermal reservoir at Soultz. Cr Geosci 342(7-8):517-530, doi:10.1016/j.crte.2009.10.002

Dieterich JH (1978) Time-dependent friction and the mechanics of stick-slip. Pure Appl Geophys 116(4-5):790-806, doi:10.1007/bf00876539 
Dolan JF, Sieh K, Rockwell TK, Yeats RS, Shaw J, Suppe J, Huftile GJ, Gath EM (1995) Prospects for larger or more frequent earthquakes in the Los Angeles metropolitan region. Science 267(5195):199-205, doi:10.1126/science.267.5195.199

Dorbath L, Cuenot N, Genter A, Frogneux M (2009) Seismic response of the fractured and faulted granite of Soultzsous-Forêts (France) to 5 km deep massive water injections. Geophys J Int 177(2):653-675, doi:10.1111/j.1365-246X.2009.04030.x

Dyer BC, Baria R, Michelet S (2003) Soultz GPK3 stimulation and GPK3-GPK2 circulation May to July 2003 seismic monitoring report. Semore Seismic report, GEIE

Economides MJ, Nolte KG, Ahmed U (1989) Reservoir stimulation, 2nd edn. Prentice Hall, Michigan

Evans KF, Genter A, Sausse J (2005a) Permeability creation and damage due to massive fluid injections into granite at $3.5 \mathrm{~km}$ at Soultz: 1. Borehole observations. J Geophys Res-Sol Ea 110(B04203):19, doi:10.1029/2004jb003168

Evans KF, Moriya H, Niitsuma H, Jones RH, Phillips WS, Genter A, Sausse J, Jung R, Baria R (2005b) Microseismicity and permeability enhancement of hydrogeologic structures during massive fluid injections into granite at $3 \mathrm{~km}$ depth at the Soultz HDR site. Geophys J Int 160(1):389-412, doi:10.1111/j.1365-246X.2004.02474.x

Fabriol H, Beauce A, Genter A (1994) Jones R (1994) induced microseismicity and its relation with natural fractures - the HDR example of Soultz (France)

Faulkner DR, Jackson CAL, Lunn RJ, Schlische RW, Shipton ZK, Wibberley CAJ, Withjack MO (2010) A review of recent developments concerning the structure, mechanics and fluid flow properties of fault zones. J Struct Geol 32 (11):1557-1575, doi:10.1016/j.jsg.2010.06.009

Genter A, Traineau H (1992) Hydrothermally altered and fractured granite as an HDR reservoir in the EPS-1 borehole, Alsace, France. In: Seventeenth workshop on geothermal reservoir engineering. Stanford University, Stanford, California, p 6

Genter A, Traineau H (1996) Analysis of macroscopic fractures in granite in the HDR geothermal well EPS-1, Soultz-sousForêts, France. J Volcanol Geoth Res 72(1-2):121-141, doi:10.1016/0377-0273(95)00070-4

Genter A, Evans K, Cuenot N, Fritsch D, Sanjuan B (2010) Contribution of the exploration of deep crystalline fractured reservoir of Soultz to the knowledge of enhanced geothermal systems (EGS). Cr Geosci 342(7-8):502-516, doi:10.1016/j.crte.2010.01.006

Groos J, Zeiß J, Grund M, Ritter J (2013) Microseismicity at two geothermal power plants in Landau and Insheim in the Upper Rhine Graben, Germany. EGU General Assembly, Vienna, Geophysical Research Abstracts

Gutenberg B, Richter C (1954) Seismicity of the earth and associated phenomena. Princeton University Press, Princeton

Häring MO, Schanz U, Ladner F, Dyer BC (2008) Characterisation of the Basel 1 enhanced geothermal system. Geothermics 37(5):469-495, doi:10.1016/j.geothermics.2008.06.002

Heinicke J, Fischer T, Gaupp R, Götze J, Koch U, Konietzky H, Stanek K-P (2009) Hydrothermal alteration as a trigger mechanism for earthquake swarms: the Vogtland/NW Bohemia region as a case study. Geophys J Int 178(1):1-13, doi:10.1111/j.1365-246X.2009.04138.x

Holmes RR, Jones LM, Eidenshink JC, Godt JW, Kirby SH, Love JJ, Neal CA, Plant NG, Plunkett ML, Weaver CS, Wein A, Perry SC (2013) U.S. Geological Survey natural hazards science strategy - promoting the safety, security, and economic well-being of the nation. US Geological Survey Circular 1383-F:79

Ikari MJ, Saffer DM, Marone C (2009) Frictional and hydrologic properties of clay-rich fault gouge. J Geophys Res Solid Earth 114(B5), B05409, doi:10.1029/2008jb006089

Ikari MJ, Marone C, Saffer DM (2011) On the relation between fault strength and frictional stability. Geology 39(1):83-86, doi:10.1130/g31416.1

Jones RH, Beauce A, Jupe A, Fabriol H, Dyer BC (1995) Imaging induced microseismicity during the 1993 injection tests at Soultz-Sous-Forêts, France. World Geothermal Congress, Florence, Italy

Kohli AH, Zoback MD (2013) Frictional properties of shale reservoir rocks. J Geophys Res Solid Earth 118(9):5109-5125, doi:10.1002/jgrb.50346

Kohonen T (1984) Self-organization and associative memory. Springer series in information sciences, vol 8, 1st edn. Springer, Berlin

Langenbruch C, Shapiro SA (2014) Gutenberg-Richter relation originates from Coulomb stress fluctuations caused by elastic rock heterogeneity. J Geophys Res Solid Earth 119(B2):15, doi:10.1002/2013jb010282

Ledésert B, Hebert R, Genter A, Bartier D, Clauer N, Grall C (2010) Fractures, hydrothermal alterations and permeability in the Soultz Enhanced Geothermal System. Cr Geosci 342(7-8):607-615, doi:10.1016/j.crte.2009.09.011

Majer EL, Baria R, Stark M, Oates S, Bommer J, Smith B, Asanuma H (2007) Induced seismicity associated with Enhanced Geothermal Systems. Geothermics 36(3):185-222, doi:http://dx.doi.org/10.1016/j.geothermics.2007.03.003

Meixner J, Schill E, Gaucher E, Kohl T (2014) Inferring the in situ stress regime in deep sediments: an example from the Bruchsal geothermal site. Geothermal Energy 2(1):1-17, doi:10.1186/s40517-014-0007-z

Meller C, Genter A, Kohl T (2014a) The application of a neural network to map clay zones in crystalline rock. Geophys J Int 196(2):837-849, doi:10.1093/gji/ggt423

Meller C, Kontny A, Kohl T (2014b) Identification and characterization of hydrothermally altered zones in granite by combining synthetic clay content logs with magnetic mineralogical investigations of drilled rock cuttings. Geophys J Int 20, doi:10.1093/gi/ggu278

Meunier A (2005) Clays, 1st edn. Springer, Berlin

Moore DE, Lockner DA (2007) Friction of the smectite clay montmorillonite: a review and interpretation of data. In: Dixon T (ed) The seismogenic zone of subduction thrust faults. Columbia Univ. Press, New York, pp 317-345

Morrow C, Radney B, Byerlee J (1992) Chapter 3 frictional strength and the effective pressure law of montmorillonite and illite clays. In: Brian E, Teng-fong W (eds) International geophysics, vol Volume 51. Academic, 88, pp 69-88, doi:10.1016/S0074-6142(08)62815-6

Mulargia F, Castellaro S, Ciccotti M (2004) Earthquakes as three stage processes. Geophys J Int 158(1):98-108, doi:10.1111/j.1365-246X.2004.02262x

Nami P, Schellschmidt R, Schindler M, Tischner T Chemical Stimulation Operations for Reservoir Development of the Deep Crystalline HDR/EGS System at Soultz-sous-Forêts (France) In: Thirty-Second Workshop on Geothermal Reservoir Engineering, Stanford, California, January 28-30, 2008 2008. Stanford University, p 11 
Ruina A (1983) Slip instability and state variable friction laws. J Geophys Res Solid Earth 88(B12):10359-10370, doi:10.1029/JB088iB12p10359

Rummel F, Klee G (1995) State of stress at the European HDR candidate sites Urach and Soultz

Sahara D, Schoenball M, Kohl T, Mueller B (2014) Impact of fracture networks on borehole breakout heterogeneities in crystalline rock. Int J Rock Mech Mining Sci 71:301-309, doi:10.1016/j.jirmms.2014.07.001

Sausse J (2002) Hydromechanical properties and alteration of natural fracture surfaces in the Soultz granite (Bas-Rhin France). Tectonophysics 348(1-3):169-185, doi:10.1016/s0040-1951(01)00255-4

Schleicher AM (2005) Clay mineral formation and fluid-rock interaction in fractured crystalline rocks of the Rhine Rift System: case studies from the Soultz-Sous-Forêts granite (France) and the Schauenburg Fault (Germany). RuprechtKarls-Universität, Heidelberg, Inaugural Dissertation

Schleicher AM, Van der Pluijm BA, Solum JB, Warr LN (2006) Origin and significance of clay-coated fractures in mudrock fragments of the SAFOD borehole (Parkfield, California). Geophys Res Lett 33(L16313):5, doi:10.1029/2006GL026505

Schmittbuhl J, Lengliné O, Zaepfel, Cornet FH, Cuenot N (2013) Genter a seismic and aseismic slip in EGS reservoir: an experimental approach. European Geothermal Congress, Pisa, Italy, p 7

Schmittbuhl J, Lengliné O, Cornet F, Cuenot N, Genter A (2014) Induced seismicity in EGS reservoir: the creep route. Geothermal Energy:

Schoenball M, Baujard C, Kohl T, Dorbath L (2012) The role of triggering by static stress transfer during geothermal reservoir stimulation. J Geophys Res Solid Earth 117(B9), B09307, doi:10.1029/2012jb009304

Schoenball M, Dorbath L, Gaucher E, Wellmann JF, Kohl T (2014) Change of stress regime during geothermal reservoir stimulation. Geophys Res Lett 41(4):1163-1170, doi:10.1002/2013gl058514

Scholz CH (2010) The mechanics of earthquakes and faulting, 2nd edn. Cambridge University Press, Cambridge

Schorlemmer D, Wiemer S (2005) Earth science microseismicity data forecast rupture area. Nature 434(7037):1086-1086, doi:10.1038/4341086a

Schorlemmer D, Wiemer S, Wyss M (2005) Variations in earthquake-size distribution across different stress regimes. Nature 437(7058):539-542, doi:10.1038/nature04094

Sibson RH (2009) Rupturing in overpressured crust during compressional inversion - the case from NE Honshu, Japan Tectonophysics 473(3-4):404-416, doi:http://dx.doi.org/10.1016/j.tecto.2009.03.016

Smith SAF, Holdsworth RE, Collettini C, Imber J (2007) Using footwall structures to constrain the evolution of low-angle normal faults. J Geol Soc 164(6):1187-1191, doi:10.1144/0016-76492007-009

Takahashi M, Mizoguchi K, Kitamura K, Masuda K (2007) Effects of clay content on the frictional strength and fluid transport property of faults. J Geophys Res Solid Earth 112(B8), B08206, doi:10.1029/2006jb004678

Tembe S, Lockner DA, Wong T-F (2010) Effect of clay content and mineralogy on frictional sliding behavior of simulated gouges: binary and ternary mixtures of quartz, illite, and montmorillonite. J Geophys Res Solid Earth 115(B3), B03416, doi:10.1029/2009jb006383

Valley B (2007) The relation between natural fracturing and stress heterogeneities in deep-seated crystalline rocks at Soultz-sous-Forêts (France), dissertation. ETH Zürich, Zürich

Valley B, Evans K (2000) Stress estimates from analysis of breakouts and drilling-induced tension fractures in GPK1 and GPK4. Synthetic final report, vol EC contract ENK5-2000-00301. ETH, Zurich

Valley B, Evans K (2003) Strength and elastic properties of the Soultz granite. In: Zürich E (ed) Synthetic 2nd year report, Zürich, Switzerland, 2003. vol EC Contract SES6-CT-2003-502706. ETH, Zürich, p 6

Valley B, Evans KF (2007) Stress state at Soultz-sous-Forêts to $5 \mathrm{~km}$ depth from wellbore failure and hydraulic observations. 32nd workshop on geothermal reservoir engineering, Stanford

Valley B, Evans KF (2010) Stress heterogeneity in the granite of the Soultz EGS reservoir inferred from analysis of wellbore failure. World Geothermal Congress, Bali, Indonesia, p 12

Velde B (ed) (1995) Origin and mineralogy of clays, 1st edn. Springer, Heidelberg

Voisin C, Cotton F, Di Carli S (2004) A unified model for dynamic and static stress triggering of aftershocks, antishocks, remote seismicity, creep events, and multisegmented rupture. J Geophys Res Solid Earth 109(B6), B06304, doi:10.1029/2003jb002886

Wu FT (1978) Mineralogy and physical nature of clay gouge. Pure Appl Geophys 116(4-5):655-689, doi:10.1007/bf00876531

Wu FT, Blatter L, Roberson H (1975) Clay gouges in the San Andreas Fault System and their possible implications. Pure Appl Geophys 113(1):87-95, doi:10.1007/bf01592901

Zoback MD, Harjes H-P (1997) Injection-induced earthquakes and crustal stress at $9 \mathrm{~km}$ depth at the KTB deep drilling site, Germany. J Geophys Res 102(B8):18477-18491, doi:10.1029/96jb02814

Zoback MD, Kohli A, Das I, McClure M (2012) The importance of slow slip of faults during hydraulic-fracturing stimulation of shale gas reservoirs. Paper presented at the Americas unconventional resources, Pittsburgh, Pennsylvania, 5-7 June 2012

doi:10.1186/s40517-014-0012-2

Cite this article as: Meller and Kohl: The significance of hydrothermal alteration zones for the mechanical

behavior of a geothermal reservoir. Geothermal Energy 2014 2:12. 